\title{
ANALISIS AGLOMERASI PADA KORIDOR EKONOMI DI INDONESIA
}

\author{
Firnanda Melia Eriandy ${ }^{1}$ \\ Email:firnandamelia@gmail.com
}

\begin{abstract}
Economic development that tends to be centered on developed regions causes a spatial concentration of economic activity. One of the efforts to build growth centers in each corridor, the Master Plan for the Acceleration of Expansion of Indonesian Economic Development (MP3EI) divides Indonesia into six economic development corridors. The purpose of this study is to determine the level of economic agglomeration in each economic corridor in Indonesia, and to analyze the determinants of economic agglomeration in these corridors. This type of research data uses secondary data consisting of time series data for 2010-2019 and cross section data of six economic corridors in Indonesia. Data analysis using Herfindahl-Hirschman Index and Panel Data Regression. The results of this study are that the regional government budget has a significant and positive effect on economic agglomeration in economic corridors in Indonesia. The number of workers has a significant and negative relationship to economic agglomeration. Meanwhile, investment does not have a significant positive effect on economic agglomeration in economic corridors in Indonesia.
\end{abstract}

Keywords: Economic Agglomeration, Regional Government Budget, Investment, Herfindahl-Hirschman Index, Panel Data Regression

\section{PENDAHULUAN}

Secara teori, aglomerasi merupakan pemusatan spasial dari aktivitas ekonomi di kawasan perkotaan dengan tujuan memperoleh penghematan akibat lokasi industry yang berdekatan (economies of proximity) yang digambarkan dengan kluster spasial dari perusahaan, tenaga kerja, dan konsumen ( Montgomery dalam Kuncoro 2002). Terbentuknya aglomerasi industri tersebut diharapkan dapat memberikan dampak yang positif terhadap pertumbuhan ekonomi. Sedangkan menurut (Kuncoro 2006), ketimpangan mengacu pada standar hidup yang relative pada seluruh masyarakat, karena aglomerasi ekonomi disebabkan oleh perbedaan faktor anugerah awal (endowment factor). Adanya heterogenitas dan beragam karakteristik suatu wilayah menyebabkan kecenderungan terjadinya aglomerasi dan antar sektor ekonomi suatu daerah.

\footnotetext{
${ }^{1}$ Corresponding author: University of Jember, Kalimantan St No.37, 68121, East Jawa, Indonesia
} 
Suatu negara memiliki tujuan untuk menyejahterakan masyarakatnya melalui peningkatan pertumbuhan ekonomi negara tersebut. Pertumbuhan ekonomi merupakan hal yang penting apabila suatu negara ingin meningkatkan kesejahteraan dan taraf hidup rakyatnya. Dampak positif dari adanya kegiatan ekonomi suatu negara yang dirasakan oleh masyarakatnya menunjukkan pertumbuhan ekonomi negara tersebut berhasil. Kemajuan dalam pembangunan ekonomi dinilai berhasil apabila pertumbuhan ekonomi negara tersebut sealu mengalami peningkatan. Pertumbuhan ekonomi merupakan kemampuan suatu negara untuk menyediakan berbagai jenis barang ekonomi yang meningkat secara jangka panjang kepada masyarakat (Kuznet dalam Todaro 2000).

Pertumbuhan ekonomi suatu negara akan terus mengalami perubahan yang dapat membentuk sebuah pola tertentu yang selanjutnya memunculkan teori tahapan pembangunan ekonomi. Berawal di tahun 1840, Friedrich List menyatakan bahwa terdapat lima tahap dalam pembangunan ekonomi dengan cara produksi, yaitu; tahap primitive; tahap beternak; tahap pertanian dan industry pengolahan; dan tahap pertanian, industry pengolahan, dan perdagangan (Bastien dalam Susanti 2018).

Pada jangka panjang, pembangunan ekonomi di suatu negara akan menciptakan perubahan struktur ekonomi negara tersebut. Diawali dengan ekonomi tradisional di sektor pertanian yang beralih ke ekonomi modern yang didominasi oleh sektor industri sebagai penggerak utama roda perekonomian. Perubahan dalam struktur ekonomi menunjukkan bahwa peningkatan pendapatan per kapita masyarakat sejalan dengan perekonomian suatu negara yang bergeser dari sektor pertanian ke sektor industri. Perubahan struktur ekonomi dapat dilihat pada perubahan nilai tambah dari setiap sektor dalam pembentukan PDB atau pendapatan nasional.

Di Negara Sedang Berkembang (NSB) seperti Indonesia, pembangunan sektor industri manufaktur merupakan prioritas utama dalam rencana pembangunan. Sektor industri dianggap berperan penting dalam mendorong perkembangan sektor lainnya, seperti jasa, perdagangan, transportasi, dan pertanian. Produk-produk industrial dinilai memiliki nilai yang lebih tinggi dan lebih menguntungkan disbanding produk-produk sektor lain. Semakin berjalannya waktu, sektor pertanian justru kurang mendapat perhatian yang mendalam karena industri manufaktur mulai diunggulkan.

Sektor industri terus mengalami perkembangan secara bertahap dan berkala di Indonesia. Maka dari itu, sektor industri memberi kontribusi yang besar terhadap Produk Domestik Bruto (PDB). Industri juga berkontribusi dalam peningkatan pendapatan masyarakat, dan sektor manufaktur juga berperan dalam peningkatan penyerapan tenaga kerja. Oleh karena itu, pertumbuhan industri di suatu wilayah akan mempengaruhi perkembangan wilayah tersebut, termasuk wilayah-wilayah di Indonesia.

Perkembangan suatu wilayah secara otomatis akan membagi wilayah tersebut menjadi dua bagian, yaitu bagian pusat kota dan bagian pinggiran kota. Pusat kota tersebut akan memanfaatkan wilayah pinggiran kota sebagai wilayah industri yang produktif sebagai upaya untuk meningkatkan pertumbuhan ekonomi wilayah. Maka dari itu, Kementerian Perindustrian Republik Indonesia akan terus 
mendorong pertumbuhan industri di Indonesia.

Sektor industri dari tahun ke tahun terus mengalami pertumbuhan, artinya pembangunan sektor industri merupakan bagian dari pembangunan ekonomi jangka panjang karena kontribusi sektor industri yang sangat besar terhadap pembentukan Produk Domestik Bruto (PDB). Berikut merupakan tabel PDB Indonesia menurut lapangan usaha selama 10 tahun terakhir, yaitu mulai tahun 2010 sampai 2019.

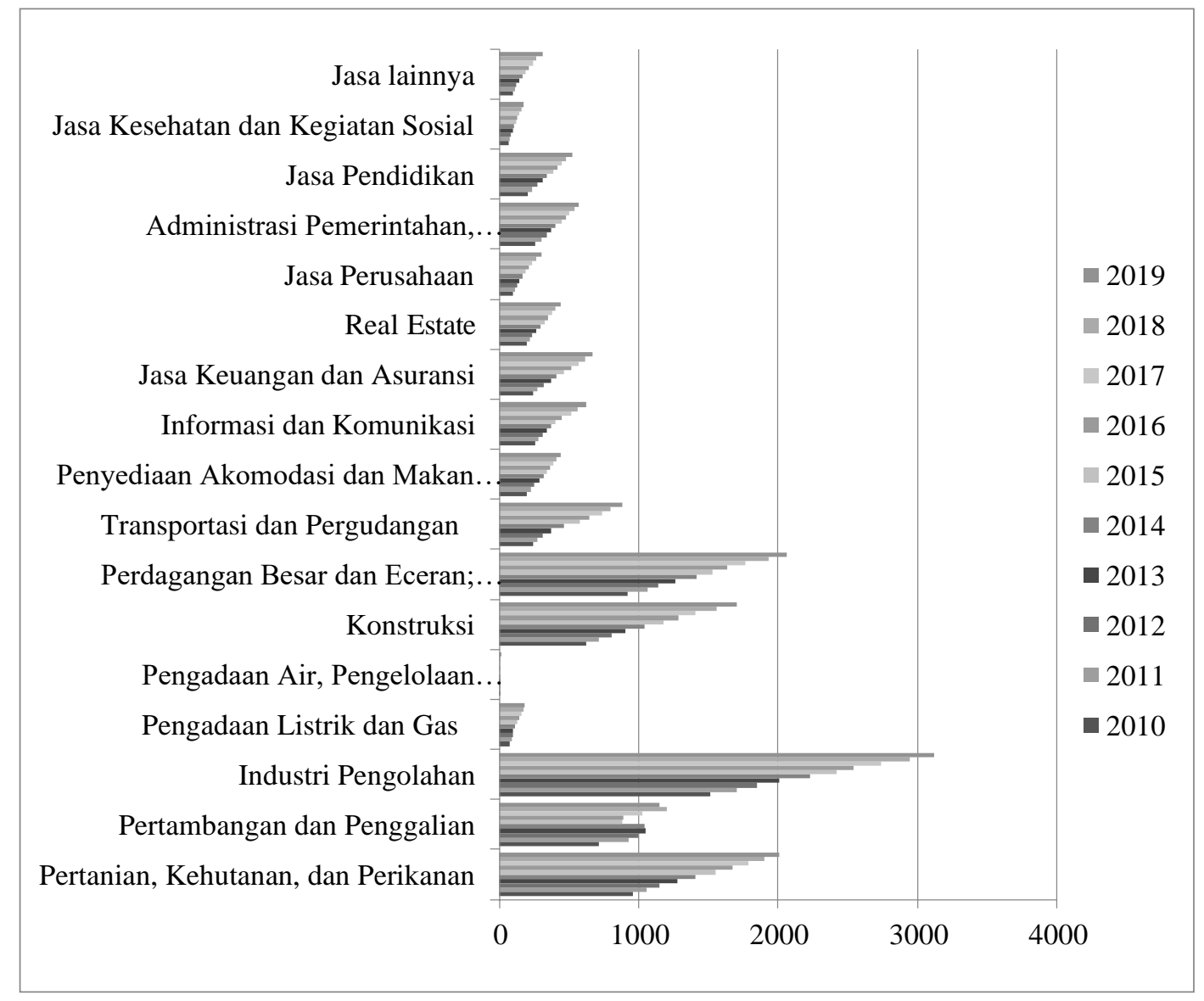

\section{Gambar 1. PDB Atas Dasar Harga Berlaku Menurut Lapangan Usaha Tahun 2010-2019 (dalam Triliun Rupiah)}

Berdasarkan gambar diatas, diketahui bahwa dari 17 sektor lapangan usaha penyumbang PDB, sektor industri merupakan penyumbang tertinggi selama 10 tahun berturut-turut, serta selalu mengalami peningkatan setiap tahunnya. Dengan begitu, industri dianggap sebagai sektor yang paling berpengaruh dalam perekonomian nasional.

Indonesia terbagi menjadi 34 Provinsi. Selain pembagian wilayah secara administratif menurut provinsi, Indonesia juga dibagi menurut daerah pembangunan ekonomi. Masterplan Percepatan Perluasan Pembangunan Ekonomi Indonesia (MP3EI) membagi Indonesia menjadi 6 koridor pembangunan ekonomi, yaitu sebagai berikut.

1. Koridor Sumatera, yang merupakan sentra produksi dan pegolahan hasil bumi dan lumbung energi nasional. 
2. Koridor Jawa, yang merupakan pendorong industry dan jasa nasional.

3. Koridor Kalimantan, yang merupakan pusat produksi dan pengolahan hasil tambang dan lumbung energi nasional.

4. Koridor Bali - Nusa Tenggara, yang merupakan pintu gerbang pariwisata nasional dan pendukung pangan nasional.

5. Koridor Sulawesi, yang merupakan pusat produksi dan pengolahan hasil pertanian, perkebunan, perikanan, migas, dan pertambangan nasional.

6. Koridor Papua - Kepulauan Maluku, yang merupakan pengembangan energi pangan, perikanan, dan tambang nasional.

Pembagian 6 koridor pembangunan ekonomi di Indonesia merupakan salah satu upaya untuk membangun pusat-pusat pertumbuhan di setiap koridor, agar terbentuk konektivitas antar koridor ekonomi, konektivitas internasional, konektivitas antar pusat pertumbuhan, serta peningkatan kualitas SDM dan ilmu pengetahuan dan teknologi. Tujuan akhirnya adalah untuk memacu pusat-pusat pertumbuhan (growth poles) yang akan mendorong pertumbuhan daerah-daerah sekitarnya. Pertumbuhan ekonomi akan lebih mudah ditingkatkan apabila industry beroperasi secara berkelompok agar menciptakan keuntungan aglomerasi yang berupa urbanization economies dan localization economies. Selanjutnya, dengan adanya aglomerasi akan menciptakan kekuatan industry nasional dalam bentuk saling terikat, saling bergantung, dan saling menunjang antara industry hulu, industry hilir, industry pendukung, dan industry terkait yang akan meningkatkan perekonomian di daerah tersebut (Tambunan 2001).

Peran pemerintah sangat dibutuhkan dalam menyejahterakan masyarakat melalui upaya-upaya guna menurunkan ketimpangan. Adanya anggaran pembangunan yang berasal dari Anggaran Pendapatan dan Belanja Daerah (APBD) diharapkan dapat mencitakan pembangunan fisik maupun non fisik yang semakin merata di seluruh Indonesia. APBD didasarkan pada skala prioritas dan plafon anggaran, rencana kerja Pemerintah Daerah dan Kebijakan Umum APBD yang terlah disepakati bersama oleh DPRD setempat dan Pemerintah Daerah. APBD tersebut diharapkan dapat meningkatkan pertumbuhan ekonomi yang bersamaan dengan menurunnya ketimpangan antarwilayah di Indonesia.

Banyaknya pulau bahkan provinsi di Indonesia menjadikannya memiliki potensi yang berbeda-beda di tiap wilayah. Ada daerah yang berpotensi di 137ndust pariwisata, pertambangan, 137ndustry, pertanian, dan lain-lain. Hal inilah yang menyebabkan distribusi pendapatan tidak merata yang akhirnya menyebabkan terjadinya aglomerasi ekonomi. Berikut merupakan data PDRB antar Koridor ekonomi di Indonesia. 


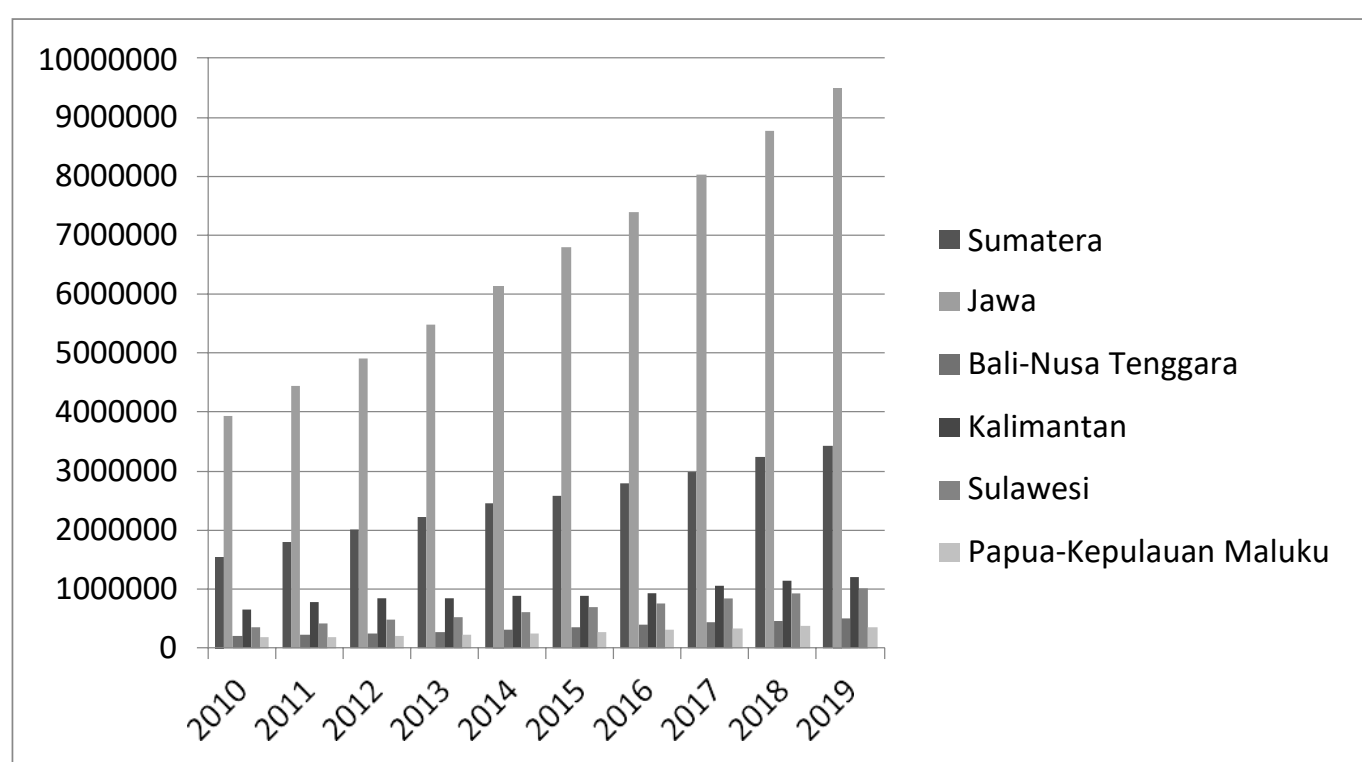

Gambar 2. PDRB antar Koridor Ekonomi di Indonesia Tahun 2010-2019 (dalam Milyar Rupiah)

Berdasarkan Gambar 2, diketahui bahwa terdapat perbedaan PDRB yang cukup signifikan di tiap-tiap koridor ekonomi. Dari 6 koridor ekonomi di Indonesia, PDRB di koridor Jawa adalah yang paling tinggi di antara koridor lainnya selama 10 tahun berturut-turur. Kemudian disusul oleh koridor Sumatera sebagai urutan kedua, selanjutnya Kalimantan, Sulawesi, Bali-Nusa Tenggara, dan yang terakhir Maluku-Papua.

Terdapat perbedaan teori antara Scott dan Stopper dengan Myrdal dan Pred dalam menjelaskan aglomerasi ekonomi. Dimana Scott dan Stopper beranggapan bahwa awal aglomerasi muncul karena para pelaku ekonomi yang berupaya untuk mendapatkan penghematan, baik penghematan lokalisasi maupun penghematan urbanisasi dengan memilih lokasi industri yang saling berdekatan. Aglomerasi ini mencerminkan adanya interaksi antara pelaku ekonomi yang sama. Kesimpulannya adalah dahwa aglomerasi ekonomi akan tetap terbentuk dan terus mengingkat seiring berjalannya waktu.

Bertentangan dengan hal tersebut, Myrdal and Pred (1957) menyatakan bahwa jika aglomerasi dapat mencapai skala ekonomi terbesar di suatu daerah, ekspansi lebih lanjut hanya akan berdampak negatif pada daerah aglomerasi. Seiring berjalannya waktu, persaingan antara perusahaan dan industri akan menyebabkan harga bahan baku dan pasokan meningkat, yang pada gilirannya akan meningkatkan biaya per unit, yang menyebabkan beralihnya kegiatan ekonomi ke daerah lain yang belum mencapai tingkat produksi tertinggi. Kesimpulannya adalah semakin tinggi aglomerasi yang terbentuk, maka akan menyebabkan spread effect ke daerah sekitarnya, yang dalam jangka panjang akan menciptakan pemerataan ekonomi.

Terdapat beberapa penelitian terkait aglomerasi, penelitian pertama berjudul Pengaruh Belanja Pemerintah Terhadap Ketimpangan Pendapatan di Jawa Timur oleh Sutiono and Syafitri (2018). Hasil dari penelitian tersebut adalah Anggaran Pendapatan dan Belanja Daerah (APBD) berpengaruh positif terhadap 
ketimpangan ekonomi. Penelitian kedua berjudul Dampak Investasi dan Tenaga Kerja Terhadap Ketimpangan Pembangunan Kawasan Timur Indonesia. Hasil dari penelitian kedua adalah tenaga kerja dan penanaman modal asing memiliki pengaruh positif terhadap ketimpangan, sedangkan penanaman modal dalam negeri tidak berpengaruh signifikan terhadap ketimpangan. Penelitian ketiga berjudul Pengaruh Investasi dan Inflasi Terhadap Pertumbuhan Ekonomi dan Ketimpangan Distribusi Pendapatan di Kabupaten Klungkung oleh (Pramesti and Yasa 2019). Hasil dari penelitian ini adalah investasi dan inflasi memiliki pengaruh positif terhadap pertumbuhan ekonomi, sedangkan pada ketimpangan distribusi pendapatan, investasi dan inflasi memiliki pengaruh yang negatif.

Berdasarkan data Rasio Gini yang dihimpun dari Badan Pusat Statistik (2020a), semua provinsi di Pulau Jawa serentak mengalami peningkatan aglomerasi ekonomi, sedangkan 21 provinsi di Luar Jawa cenderung mengalami penurunan. Penurunan tertinggi terjadi pada Provinsi Kalimantan Timur, yaitu mengalami penurunan sebesar 0,007. Rasio gini tertinggi terjadi di Yogyakarta, dengan angka 0,403 pada 2019. Sedangkan tingkat aglomerasi terendah terjjadi di Bangka Belitung, yaitu sebesar 0,262. Perbedaan jumlah Anggaran Pendapatan dan Belanja Daerah (APBD), jumah tenaga kerja, dan investasi di tiap-tiap koridor akan mempengaruhi tingkat aglomerasi ekonomi di wilayah yang bersangkuatan. Sesuai dengan latar belakang dan permasalah yang terlah diuraikan di atas, peneliti tertarik untuk menganalisia lebih lanjut terkait aglomerasi ekonomi di antara koridor ekonomi di Indonesia. Adapun judul yang kemudian digunakan peneliti adalah "Analisis Aglometari pada Koridor Ekonomi di Indonesia."

\section{KAJIAN LITERATUR DAN PENGEMBANGAN HIPOTESIS Teori Aglomerasi}

a. Teori Klasik

Teori Klasik terkait aglomerasi menyatakan bahwa awal aglomerasi muncul karena para pelaku ekonomi berupaya untuk mendapatkan penghematan, baik penghematan lokalisasi maupun penghematan urbanisasi dengan memilih lokasi industri yang saling berdekatan. Aglomerasi ini mencerminkan adanya interaksi antara pelaku ekonomi yang sama: antar perusahaan dalam industri yang sama; antar perusahaan dalam industri yang berbeda; dan atau antar individu, perusahaan, dan rumah tangga. Terdapat pendekatan lain yang mengaitkan aglomerasi sebagai suatu bentuk spasial dengan konsep penghematan aglomerasi melalui konsep eksternalitas. Para ekonom Klasik membedakan antara (1) penghematan internal dan eksternal; (2) penghematan akibat skala ekonomis dan cakupan, (Scott and Stopper dalam Kuncoro 2002).

Penghematan internal adalah suatu pengurangan biaya internal dalam suatu perusahaan yang tercapai akibat adanya peningkatan efisiensi proses produksi. Sedangkan penghematan eksternal merupakan pengurangan biaya yang terjadi akibat aktivitas di luar ruang lingkup perusahaan yang dapat dicapai dengan beberapa industri yang beraglomerasi di suatu wilayah. Penghematan akibat skala ekonomi terjadi apabila perusahaan menambah hasil produksi dengan cara memperbesar pabrik (skala ekonomi sehingga biaya produksi per unit dapat ditekan). Perusahaan yang memperbesar skala ekonomi nantinya akan membutuhkan tenaga kerja yang semakin banyak. Sedangkan penghematan akibat 
cakupan terjadi apabila sejumlah aktivitas internal maupun eksternal dapat dilakukan secara bersamaan sehingga menghemat biaya.

b. Teori Neoklasik (Krugman)

Teori Neoklasik memperkenalkan kita pada ekonomi aglomerasi dan kelebihannya. Para pionir teori neoklasik percaya bahwa aglomerasi berawal dari perilaku para pelaku ekonomi yang berusaha untuk memperolah penghematan, termasuk penghematan yang terlokalisasi dan penghematan yang terurbanisasi (Kuncoro 2002). Dalam teori perkotaan Neoklasik, diasumsikan bahwa ada persaingan sempurna, sehingga kekuatan sentripetal aglomerasi disebut ekonomi eksternal murni (Krugman 1998). Versi Neoklasik dari perkotaan mencoba untuk menggambarkan kekuatan sentripetal aglomerasi sebagai penghematan eksternal.

Salah satu temuan penting dalam teori Neoklasik adalah adanya keuntungan- keuntungan dari aglomerasi ekonomi (Peer dalam Kuncoro 2002). Para pionir teori NCT percaya bahwa aglomerasi muncul dari perilaku pelaku ekonomi yang berusaha mencapai skala ekonomi di lokasi dan urbanisasi melalui aglomerasi. Klaster industri berdasarkan penelitian Marshall memberikan beberapa keuntungan melalui eksternalitas yang terkait secara geografis. Teori lokasi tradisional percaya bahwa kelompok industri terutama berasal dari biaya transportasi dan manufaktur (Isard, 1956; Weber, 1909, dalam Kuncoro 2002). Teori-teori ini melibatkan berbagai asumsi, yaitu lokasi geografis atau basis bahan baku, skala konsumsi, dan tenaga kerja tidak mudah untuk dipindahkan, dan kuantitas yang dianggap tak terbatas, dianggap konstan. Wilayah memberikan berbagai manfaat terkait produktivitas dan pendapatan yang lebih tinggi, yang dapat sangat menarik peluang investasi baru, inovasi teknologi, tenaga kerja terampil, dan tingkat pendidikan yang lebih tinggi. Versi neoklasik dari perkotaan mencoba untuk menggambarkan kekuatan sentripetal aglomerasi sebagai ekonomi eksternal. Model tersebut juga menjelaskan bahwa gaya sentrifugal yang dihasilkan oleh perpindahan ke pusat kota disebut Central Business District (CBD) di kota manapun.

\section{Teori Eksternalitas Dinamis}

Teori eksternalitas dinamis didasarkan pada teori Marshall Arrow Romer (MAR), Porter, dan Jacob. Teori ini menjelaskan bagaimana sebuah kota muncul dan mengapa ia dapat berkembang (Sodik et al. 2007). Efek eksternal dari MAR adalah menekankan bahwa transfer pengetahuan merupakan pemicu terjadinya aglomerasi ekonomi. Menurut MAR, monopoli lokal lebih baik daripada kompetinsi lokal karena monopoli dapat menghambat inovasi di industri lain. Serupa dengan MAR, Porter menegaskan kembali bahwa konsentrasi industri akan mendorong pertumbuhan melalui transfer pengetahuan tertentu. Dibandingkan dengan MAR, kompetisi lokal lebih penting untuk mempercepat adaptasi inovasi. Sedangkan Jacob percaya bahwa transfer pengetahuan yang paling penting berasal dari industri besar. Keragaman industri terkait akan mendorong inovasi dan pertumbuhan.

Pertumbuhan penduduk berkaitan dengan peningkatan kegiatan ekonomi, yang akan memiliki efek eksternal. Ketika kegiatan suatu entitas ekonomi mempengaruhi kepentingan entitas ekonomi lainnya dan terjadi di luar 
mekanisme pasar (non-market mechanism), maka akan muncul eksternalitas. Jika eksternalitas tidak dapat ditransfer melalui mekanisme harga pasar, maka akan mempengaruhi efisiensi ekonomi. Karena individu atau lembaga atau negara tidak dapat menciptakan hak milik, eksternalitas dapat terjadi (Snyder et al. 2012). Eksternalitas juga dapat diartikan sebagai biaya, manfaat, atau hasil transaksi ekonomi. Oleh karena itu, harga pasar yang dihasilkan tidak dapat secara akurat menggambarkan biaya dan manfaat sosial marjinal (Hyman 2014).

\section{Teori Ekonomi Geografi Baru}

Teori Geoekonomi baru bertujuan untuk mengurangi efek aglomerasi dari interaksi antara ukuran pasar, biaya transportasi, dan peningkatan keuntungan perusahaan daerah. Konsentrasi geografis pasar sumber daya lokal menyebabkan perbedaan dan tekanan produksi, yang memberikan harga lebih tinggi dan menciptakan permintaan. Jika biaya transportasi cukup rendah, itu akan terbentuk aglomerasi. Manfaat partisipasi akan bertambah seiring dengan bertambahnya jumlah perusahaan. Karena interaksi ini bersifat informal, peningkatan pertukaran informasi menurun seiring dengan jarak. Hal ini akan mendorong pelaku usaha untuk mendirikan usaha yang berdekatan dengan usaha lain dan membuat klaster yang tentunya akan meningkatkan pendapatan daerah setempat.

Tingkat pertukaran informasi menurun dengan meningkatnya jarak. Myrdal and Pred (1957) berpendapat bahwa dampak positif dari aglomerasi disebut ekonomi aglomerasi, yang berarti pembentukan industri baru meningkatkan kesempatan kerja, meningkatkan daya tarik dan modal kerja, meningkatkan keterampilan masyarakat sekitar, dan memperluas jasa lokal, populasi, layanan, dengan biaya satuan yang lebih rendah. Jika aglomerasi dapat mencapai skala ekonomi terbesar di suatu daerah, ekspansi lebih lanjut hanya akan berdampak negatif pada daerah aglomerasi. Seiring berjalannya waktu, persaingan antara perusahaan dan industri akan menyebabkan harga bahan baku dan pasokan meningkat, yang pada gilirannya akan meningkatkan biaya per unit, yang menyebabkan beralihnya kegiatan ekonomi ke daerah lain yang belum mencapai tingkat produksi tertinggi.

\section{Hipotesis}

1. APBD diduga memiliki pengaruh yang positif dan signifikan terhadap aglomerasi ekonomi pada koridor-koridor ekonomi di Indonesia.

2. Tenaga kerja memiliki pengaruh yang positif dan signifikan terhadap aglomerasi ekonomi pada koridor-koridor ekonomi di Indonesia.

3. Investasi memiliki pengaruh yang positif dan signifikan terhadap aglomerasi ekonomi pada koridor-koridor ekonomi di Indonesia.

\section{METODE PENELITIAN}

\section{Jenis Penelitian}

Penelitian ini menggunakan jenis penelitian penelitian eksplanatori yang bertujuan untuk menguji hubungan antarvariabel untuk diuji kebenarannya. Selain itu, penelitian ini dilakukan dengan metode pendekatan kuantitatif. Pendekatan kuantitatif adalah pendekatan yang menggunakan data numerik dan melakukan 
proses penilitian yang menghhasilkan pengukuran yang obyektif menggunakan analisis statistik. Alasan penulis menggunakan pendekatan kuantitatif adalah dengan mempertimbangkan pendapat Suharsimi (2006) mengenai sifat umum penelitian kuantitatif, antara lain: (a) terdapat kejelasan unsur, tujuan subjek, sumber data, (b) dapat menggunakan sampel, (c) kejelasan desain penelitian, (d) analisis data dilakukan setelah semua data terkumpul.

\section{Lokasi dan Waktu Penelitian}

Penelitian ini difokuskan pada pengukuran tingkat aglomerasi ekonomi antar koridor ekonomi di Indonesia. Lokasi penelitian difokuskan di 6 koridor ekonomi di Indonesia, yaitu Koridor Sumatera, Jawa, Bali - Nusa Tenggara, Kalimantan, Sulawesi, dan Papua - Kepulauan Maluku. Waktu penelitian yang diambil adalah tahun 2010-2019.

\section{Jenis dan Sumber Data}

Penelitian ini menggunakan data sekunder yang telah dihimpun dari berbagai sumber antara lain BPS serta beberapa sumber terkait lainnya. Data sekunder meliputi: (1) PDB Indonesia atas dasar harga berlaku tahun tahun 20102019 berdasarkan koridor pembangunan; (2) jumlah populasi di Indonesia tahun 2010- 2019; (3) data APBD Provinsi dan Kabupaten di seluruh Indonesia tahun 2010-2019; (5) data jumlah tenaga kerja menurut provinsi di Indonesia tahun 2010-2019; (6) data penanaman modal dalam negeri dan penanaman modal asing menurut provinsi tahun 2010-2019; dan (7) data pendukung lainnya seperti kondisi geografis dan demografis provinsi pada masing-masing koridor ekonomi di Indonesia.

\section{Model Analisis}

\section{a. Menghitung Indeks Aglomerasi}

Salah satu pendekatan yang digunakan dalam menganalisis konsentrasi spasial suatu industri yaitu Indeks Herfindahl. Rumus Indeks Herfindahl adalah sebagai berikut:

$$
H H I=\frac{i=1^{\Sigma}, i \neq j\left(\frac{Y i}{Y}\right)^{2}}{\left(i=1^{\Sigma}, i \neq j \frac{Y i}{Y}\right)^{2}}
$$

\section{Dimana: \\ HHI : Nilai Indeks Herfindahl-Hirschman \\ $\mathrm{Yi} \quad$ : PDRB koridor $\mathrm{i}$ \\ Y : PDB total}

Nilai minimum indeks Herfindahl adalah 0 yang artinya tidak ada konsentrasi atau terdapat keanekaragaman yang sempurna. Nilai maksimum indeks ini adalah 1 yang berarti terdapat konsentrasi pada satu koridor saja. kriteria penilaian HHI adalah 0-0,15 yang berarti aglomerasi rendah, 0,15-0,25 yang berarti aglomerasi sedang, dan 0,25-1,00 yang berarti aglomerasi tinggi.

b. Analisis Regresi Linier Berganda dengan Data Panel 
Regresi panel data merupakan metode regresi yang menggabungkan data cross section dan data time series sehingga yang diamati adalah unit-unit individu yang sama dalam kurun waktu tertentu. Secara umum, data panel dicirikan oleh $\mathrm{T}$ periode waktu $(\mathrm{t}=1,2, \ldots \mathrm{T})$ yang kecil dan $\mathrm{N}$ jumlah individu $(\mathrm{i}=1,2, \ldots, \mathrm{N})$ yang besar. Variabel bebas yang digunakan terdiri atas Variabel bebas yang digunakan terdiri atas tenaga kerja, Upah minumim provinsi, dan panjang jalan. Dengan demikian model regresi yang digunakan adalah sebagai berikut:

$$
\mathrm{Ag}=\beta_{0}+\beta_{1} \ln A \mathrm{PBD}_{\mathrm{it}}+\beta_{2} \ln \mathrm{lK}_{\mathrm{it}}+\beta_{3} \ln \ln v_{\mathrm{it}}+\varepsilon_{i t}
$$

\section{Dimana:}

Ag : Aglomerasi ekonomi provinsi i pada tahun $\mathrm{t}$

$\beta_{0} \quad$ : Koefisien intersep yang merupakan skala

$\beta_{1}, \beta_{2}, \beta_{3} \quad$ : Koefisien slope atau kemiringan

lnAPBD : log natural APBD koridor i pada tahunt

$\operatorname{lnTK} \quad: \log$ natural Tenaga Kerja koridor i pada tahun $\mathrm{t}$

lnInv $\quad: \log$ natural Investasi koridor i pada tahunt

$\varepsilon \quad:$ : Error term

i $\quad: 1,2, \ldots \mathrm{n}$, menunjukkan jumlah lintas individu (cross section)

$\mathrm{t} \quad: 1,2, \ldots \mathrm{t}$, menunjukkan dimensi runtun waktu (time series)

c. Estimasi Data Panel

Dalam metode estimasi model regresi dapat dilakukan dengan tiga pendekatan, diantaranya:

1) Common Effect

Common effect merupakan pendekatan model data panel yang mengkombinasikan data time series dan cross section tanpa memperhatikan dimensi waktu maupun individu, sehingga diasumsikan bahwa data yang digunakan akan sama dalam berbagai kurun waktu. Metode ini dapat menggunakan pendekatan Ordinary Last Square (OLS) atau kuadrat kecil untuk mengestimasi model data panel.

2) Fixed Effect

Fixed effect mengasumsikan bahwa perbedaan antar individu dapat dilihat dari intersepnya. Untuk mengestimasi data panel, digunakan teknik variabel dummy untuk menangkap perbedaan intersep.

3) Random Effect

Random effect mengestimasi data panel dimana variabel gangguan mungkin saling berhubungan antarwaktu dan antarindividu. Keuntungan menggunakan model ini yakni menghilangkan heteroskedastisitas. Model ini juga disebut dengan Error Component Model (ECM) atau Generalized Least Square (GLS).

d. Uji Pemilihan Model

Dalam menentukan model panel data terbaik yang digunakan, harus dilakukan suatu pengujian pemilihan model. Pengujian model dilakukan dengan uji Hausman, uji Chow, dan Uji Lagrange.

1) Uji Hausman 
Uji Hausman dilakukan untuk menentukan model terbaik antara model fixed effect dan model random effect. Hipotesis yang digunakan pada uji Hausman yaitu :

H0 : Model random effect

H1 : Model fixed effect

Jika nilai statistik Hausman hasil pengujian lebih besar dari ChiSquare tabel, maka cukup bukti untuk memutuskan tolak H0 sehingga model terbaik yang digunakan yaitu fixed effect model.

2) Uji Chow

Uji Chow dilakukan untuk menentukan model terbaik antara model fixed Effect dan model common Effect. Hipotesis yang digunakan pada uji Chow yaitu:

H0 : Model common effect

H1 : Model fixed effect

Jika hasil dari uji Chow menunjukkan nilai probabilitas kurang dari taraf nyata $(\alpha)$, maka keputusannya H0 ditolak sehingga model terbaik yang digunakan adalah fixed effect model.

3) Uji Lagrange Multiplier

Uji lagrange multiplier dilakukan untuk menentukan model terbaik antara common effect dan random effect. Hipotesis yang digunakan adalah:

H0: Model common effect

H1: Model random effect

Jika hasil dari uji Lagrange Multiplier menunjukkan nilai probabilitas kurang dari taraf nyata $(\alpha)$, maka keputusannya H0 ditolak sehingga model terbaik yang digunakan adalah random effect.

e. Uji Asumsi Klasik

Uji asumsi klasik ditujukan untuk mengetahui adanya normalitas residual, multikolinearitas, dan heteroskedastisitas pada model regresi yan digunakan.Uji asumsi klasik digunakan agar dapat mengetahui ada atau tidaknya normalitas residual, multikolinearitas, dan heteroskedastisitas pada suatu model regresi. Model regresi linear menjadi model yang baik apabla memenuhi beberapa uji asumsi klasik.

1) Uji Normalitas

Uji normalitas untuk melihat apakah nilai residual terdistribusi normal atau tidak. Model regresi yang baik adalah memiliki nilai residual yang terdistribusi normal. Jadi uji normalitas bukan dilakukan pada masingmasing variabel, melainkan pada nilai residualnya. Uji ini dapat dilakukan dengan uji histogram, uji normal P Plot, uji Chi-Square, Skewness dan Kurtosis, atau Uji Kolmogorov Smirnov.

2) Uji Multikolinearitas

Uji multikoleniaritas untuk melihat ada atau tidaknya korelasi yang tinggi antara variabel-variabel bebas dalam suatu model regresi linier berganda. Jika terdapat korelasi yang tinggi antara variabel-variabel bebasnya, maka hubungan antara variabel bebas dan variabel terikat akan terganggu. Alat statistic yang sering digunakan untuk menguji gangguan multikolinearitas adalah dengan variance inflation factor 
(VIF), korelasi pearson, atau dengan melihat eigenvalues dan condition index $(\mathrm{Ci})$.

3) Uji Heteroskedastisitas

Uji heteroskedastisitas adalah untuk melihat apakah terdapat ketidaksamaan varians antar residual satu pengamatan ke pengamatan lain. Model regresi yang memenuhi syarat adalah dimana terdapat kesamaan varians. Uji statistic yang dapat digunakan adalah uji Glejser, uji Park, dan uji White.

4) Uji Autokorelasi

Uji autokorelasi untuk melihat apakah terjadi korelasi antara suatu periode $\mathrm{t}$ dengan periode sebelumnya (t-1). Uji autokorelasi hanya dilakukan pada data time series dan tidak perlu dilakukan pada data cross section. Beberapa uji statistic yang dapat digunakan adalah uji Durbin-Watson dan uji dengan Run Test.

f. Uji Statistik

1) $\mathrm{Uji}-\mathrm{F}$

$\mathrm{Uji}-\mathrm{F}$ adalah statistik uji yang digunakan untuk mengetahui pengaruh variabel bebas terhadap variabel terikat secara keseluruhan. Hipotesisnya yaitu:

$\mathrm{H} 0: \beta_{1}=\beta_{2}=\ldots=\beta_{\mathrm{t}}=0$

$\mathrm{H} 1$ : minimal ada satu $\beta_{\mathrm{t}} \neq 0$

Jika nilai probabilitas F-statistic $<$ taraf nyata $(\alpha)$, maka keputusannya $\mathrm{H} 0$ ditolak sehingga kesimpulannya adalah minimal ada satu variabel bebas yang memengaruhi variabel terikat.

2) $\mathrm{Uji}-\mathrm{t}$

Dalam penelitian ini uji $-\mathrm{t}$ digunakan untuk mengetahui pengaruh masing- masing variabel bebas yang menjadi faktor-faktor dalam memengaruhi aglomerasi industri. Hipotesis dalam uji $-\mathrm{t}$ yaitu:

$$
\begin{aligned}
& \mathrm{H} 0: \beta_{\mathrm{t}}=0 \text { dengan } \mathrm{t}=1,2,3, \ldots, \mathrm{n} \\
& \mathrm{H} 1: \neq 0
\end{aligned}
$$

Jika nilai probabilitas t-statistic $<$ taraf nyata $(\alpha)$, maka keputusannya tolak H0. Dengan demikian dapat disimpulkan variabel bebas yang diuji berpengaruh signifikan terhadap aglomerasi.

3) Uji R2

Uji koefisien determinasi atau uji R2 dilakukan untuk mengukur besarnya keragaman variabel terikat yang mampu dijelaskan oleh variabel-variabel bebas yang terdapat di dalam model. Nilai R2 berkisar antara 0 sampai 1 . Nilai R2 yang semakin mendekati 1 menunjukkan semakin baik keragaman variabel terikat yang mampu dijelaskan oleh variabel-variabel bebas tersebut. 


\section{HASIL PENELITIAN DAN PEMBAHASAN Analisis Indeks Herfindahl-Hirschman}

Koridor ekonomi di Indonesia memiliki tingkat aglomerasi ekonomi bervariasi. Koridor Sumatera memiliki hasil aglomerasi ekonomi yang sedang mulai tahun 2010 hingga 2019. Koridor Jawa memiliki hasil aglomerasi ekonomi yang tinggi pada tahun 2010 hingga 2019. Koridor Bali - Nusa Tenggara, Kalimantan, Sulawesi, Papua-Kepulauan Maluku memiliki hasil aglomerasi ekonomi rendah mulai tahun 2010 hingga 2019.

\section{Pemilihan Model Regresi Terbaik}

Pengaruh besarnya Anggaran Pendapatan dan Belanja Daerah, jumlah tenaga kerja, dan investasi terhadap aglomerasi ekonomi dianalisa dengan Regresi Data Panel dengan menggunakan Eviews. Terdapat tiga model dalam pengujian regresi data panel, yaitu Common Effect Model, Fixed Effect Model, dan Random Effect Model. Terpilihnya model terbaik dapat dilakukan dengan tiga pengujian, yaitu Uji Chow, Uji Hausman, dan Uji Lagrange Multiplier. Setelah terpilihnya model terbaik, selanjutnya dilakukan uji asumsi klasik, yang terdiri dari Uji Normalitas, Uji Multikolinearitas, Uji Heteroskedastisitas, dan Uji Autokorelasi. Pengujian asumsi klasik ini bertujuan untuk memastikan data yang diolah memiliki hasil yang valid secara teori, tidak bias, konsisten, dan memiliki penafsiran koefisien regresi yang efisien (Gujarati 2003). Tahap akhir dari regresi data panel adalah dengan melakukan Uji-T, Uji-F, dan koefisien determinasi. Berikut merupakan hasil olah data dengan menggunakan Eviews.

a. Uji Pemilihan Model

1) Uji Chow

Uji Chow memiliki fungsi untuk memilih model estimasi antara Common Effect Model (CEM) atau Fixed Effect Model (FEM), dengan hipotesis sebagai berikut.

H0: Model terpilih adalah CEM

H1: Model terpilih adalah FEM

Tabel 1. Hasil Uji Chow

\begin{tabular}{lrrr}
\hline Effects Test & Statistic & d.f. & Prob. \\
\hline Cross-section F & 1719.645996 & $(5,51)$ & 0.0000 \\
Cross-section Chi-square & 308.003997 & 5 & 0.0000 \\
\hline
\end{tabular}

Hasil Uji Chow menunjukkan nilai probabilitas Chi-square sebesar $0.0000<\propto=5 \%=0.05$, maka Fixed Effect Model adalah model terbaik yang terpilih dibandingkan dengan Common Effect Model atau H0 ditolak dan $\mathrm{H} 1$ diterima.

2) Uji Hausman

Uji Hausman memiliki fungsi untuk memilih model estimasi terbaik antara Random Effect Model (REM) atau Fixed Effect Model (FEM), dengan hipotesis sebagai berikut.

H0: Model terpilih adalah REM

H1: Model terpilih adalah FEM 
Tabel 2. Hasil Uji Hausman

\begin{tabular}{lccc}
\hline \hline Test Summary & Chi-Sq. Statistic Chi-Sq. d.f. & Prob. \\
\hline \hline Cross-section random & 33.157659 & 3 & 0.0000 \\
\hline \hline
\end{tabular}

Hasil Uji Hausman menunjukkan nilai probabilitas sebesar 0.0000 $<\propto=5 \%=0.05$, maka Fixed effect Model adalah model terbaik yang terpilih dibandingkan dengan Random Effect Model atau H1 diterima dan $\mathrm{HO}$ ditolak.

b. Hasil Estimasi Fixed effect Model (FEM)

Setelah dilakukan tiga rangkaian uji penentuan model terbaik, terpilihlah Fixed effect Model. Berikut merupakan tabel yang menunjukkan hasil estimasi data dengan jumlah observasi sebanyak 6 Koridor Ekonomi selama kurun waktu 2010 hingga 2019.

Tabel 3. Hasil Estimasi Fixed effect Model

\begin{tabular}{lrrrr}
\hline \multicolumn{1}{c}{ Variable } & Coefficient & Std. Error & t-Statistic & Prob. \\
\hline APBD & 232.7145 & 52.07586 & 4.468760 & 0.0000 \\
TENAGA_KERJA & -993.6805 & 231.3487 & -4.295163 & 0.0001 \\
INVESTASI & 2.635911 & 20.55884 & 0.128213 & 0.8985 \\
C & 10179.73 & 2567.912 & 3.964204 & 0.0002 \\
\hline
\end{tabular}

Effects Specification

Cross-section fixed (dummy variables)

R-squared

Adjusted R-squared

S.E. of regression

Sum squared resid

Log likelihood

F-statistic

Prob(F-statistic)
0.999333 Mean dependent var

0.999228 S.D. dependent var

55.10060 Akaike info criterion

154839.9 Schwarz criterion

-320.8104 Hannan-Quinn criter.

9552.014

0.000000
1666.700

1983.662

10.99368

11.30783

11.11656

Durbin-Watson stat $\quad 0.607734$

Berdasarkan hasil estimasi diatas, dapat dibuat model analisis data panel terhadap determinan aglomerasi ekonomi pada koridor-koridor ekonomi di Indonesia, yang disimpulkan dengan persamaan regresi berikut.

$$
\begin{gathered}
\mathrm{Ag}=\alpha 10179.73+\beta_{1} 232.7145 \text { APBD }-\beta_{2} 993.6805 \text { Tenaga Kerja }+ \\
\beta_{3} 2.635911 \text { Investasi }
\end{gathered}
$$

Berdasarkan hasil estimasi, besaran koefisien dan probabilitas dari tiap variabel memiliki hasil yang berbeda. Hasil estimasi diatas dapat diintrepetasikan sebagai berikut.

1) $\alpha=10179.73$, dapat diartikan bahwa apabila semua variabel bebas (APBD, tenaga kerja, dan investasi) dianggap konstan atau tidak mengalami perubahan, maka aglomerasi ekonomi akan sebesar 10179.73) 
2) $\beta_{1}=232.7145$, dapat diartikan bahwa apabila jumlah APBD naik satu persen, maka aglomerasi ekonomi akan mengalami peningkatan sebesar 232.7145 persen. Variabel APBD dalam hasil estimasi menunjukkan nilai probabilitas sebesar 0.0000 lebih kecil dari $a=5 \%$ yang berarti APBD memiliki pengaruh yang signifikan terhadap aglomerasi ekonomi.

3) $\beta_{2}=-993.6805$, dapat diartikan bahwa apabila jumlah tenaga kerja naik satu persen, maka aglomerasi ekonomi akan mengalami penurunan sebesar 993.6805 persen. Variabel tenaga kerja dalam hasil estimasi menunjukkan nilai probabilitas sebesar 0.0001 lebih kecil dari $a=5 \%$ yang berarti jumlah tenaga kerja memiliki pengaruh yang signifikan terhadap aglomerasi ekonomi.

4) $\beta_{3}=2.635911$, dapat diartikan bahwa apabila investasi naik satu persen, maka aglomerasi ekonomi akan mengalami kenaikan sebesar 2.635911 persen. Variabel investasi dalam hasil estimasi menunjukkan nilai probabilitas sebesar 0.8985 lebih besar dari $a=5 \%$ yang berarti investasitidak berpengaruh signifikan dan berhubungan positif terhadap aglomerasi ekonomi.

c. Hasil Uji Statistik

Setelah menginterpretasikan hasil estimasi, selanjutnya dilakukan Uji-F. Uji- $F$ dilakukan untuk mengetahui keseluruhan pengaruh dari APBD, tenaga kerja, dan investasi terhadap aglomerasi ekonomi pada koridor ekonomi di Indonesia. Berdasarkan hasil regresi dari pengaruh APBD, tenaga kerja, dan investasi terhadap aglomerasi ekonomi, diketahui bahwa nilai F-statistik sebesar 9552.014 dengan nilai F-tabel sebesar 2.769431. F-statistik yang lebih besar dari F-tabel menandakan bahwa secara bersama-sama APBD, tenaga kerja, dan investasi memiliki pengaruh signifikan terhadap aglomerasi ekonomi. Selain itu, dalam hasil regresi menunjukkan nilai probabilitas F-statistik sebesar 0.000000 lebih kecil dibandingkan dengan $\alpha=5 \%$, yang menandakan APBD, tenaga kerja, dan investasi memiliki pengaruh yang signifikan terhadap aglomerasi ekonomi.

Setelah dilakukan Uji-F, selanjutnya dilakukan Uji-T. Uji-T dilakukan dengan membandingkan aantara t-statistik dan t-tabel serta membandingkan probabilitas $\mathrm{t}$-statistik dengan tingkat $\alpha=5 \%$. Uji-T bertujuan untuk melihat besarnya pengaruh variabel bebas secara individu terhadap variabel terikat. Berikut merupakan tabel Uji-T dari APBD, tenaga kerja, dan investasi terhadap aglomerasi ekonomi pada koridorkoridor ekonomi di Indonesia tahun 2010 sampai 2019. 


\begin{tabular}{lccc}
\multicolumn{4}{c}{ Tabel 4. Hasil Uji-T } \\
\hline Variabel Bebas & t-statistik & Probabilitas & Tingkat $\boldsymbol{a}$ \\
\hline APBD & 4.468760 & 0.0000 & $5 \%=0.05$ \\
\hline Tenaga Kerja & -4.295163 & 0.0001 & $5 \%=0.05$ \\
\hline Investasi & 0.128213 & 0.8985 & $5 \%=0.05$
\end{tabular}

Tabel 4 dapat diinterpretasikan sebagai berikut.

1) Variabel APBD memiliki nilai t-statistik sebesar 4.468760 dengan nilai t- tabel sebesar 2.001717 dan memiliki nilai probabilitas sebesar 0.0000 dengan tingkat $a$ sebesar 0.05, yang berarti bahwa APBD berpengaruh secara positif dan signifikan terhadap aglomerasi ekonomi dengan tingkat kebenaran sebesar $95 \%$.

2) Variabel tenaga kerja memiliki nilai t-statistik sebesar -4.295163 dengan nilai t-tabel sebesar 2.001717 dan memiliki nilai probabilitas sebesar 0.0001 dengan tingkat $a$ sebesar 0.05, yang menandakan bahwa tenaga kerja berpengaruh negatif dan signifikan terhadap aglomerasi ekonomi dengan tingkat kebenaran sebesar $95 \%$.

3) Variabel investasi memiliki nilai t-statistik sebesar -0.128213 dengan nilai t- tabel sebesar 2.001717 dan memiliki nilai probabilitas sebesar 0.8985 dengan tingkat $a$ sebesar 0.05 , yang menandakan bahwa investasi berpengaruh positif namun tidak signifikan terhadap aglomerasi ekonomi dengan tingkat kebenaran sebesar 95\%.

Uji statistik yang terakhir dilakukan adalah dengan uji Koefisien Determinasi (R-square). Koefisien determinasi dilakukan untuk mengatahui besarnya pengaruh variabel bebas terhadap variabel terikat, selain itu juga digunakan untuk mengukur tingkat keberhasilan model regresi yang digunakan untuk memperkirakan nilai pada variabel bebasnya. Berdasarkan hasil estimasi Random Effect Model pada Tabel 4.8 , dapat dilihat jika nilai $R$-square adalah sebesar 0.999228, yang berarti pengaruh variabel APBD, jumlah tenaga kerja, dan investasi terhadap aglomerasi ekonomi adalah sebesar $99 \%$ dan sisanya sebesar $1 \%$ dipengaruhi oleh faktor lain di luar model.

d. Uji Asumsi Klasik

1) Uji Normalitas

Salah satu cara yang dapat digunakan untuk pengujian normalitas dapat dilakukan dengan melihat nilai dari probabilitas Jarque-Berra. Apabila nilai probabilitas Jarque-Berra lebih besar dari tingkat $a=5 \%$, maka data terdistribusi normal, begitu pula sebaliknnya. 


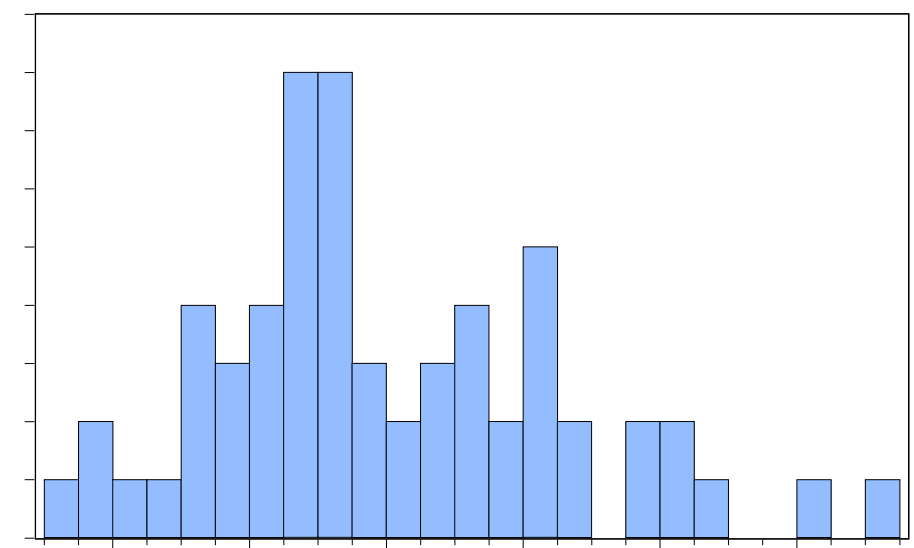

Series: Standardized Residuals Sample 20102019

Observations 60

Mean $\quad 6.24 \mathrm{e}-14$

Median $\quad-14.15432$

Maximum 144.2826

Minimum $\quad-94.84203$

Std. Dev. $\quad 51.22895$

Skewness $\quad 0.616165$

Kurtosis $\quad 3.160163$

Jarque-Bera 3.860722

Probability $\quad 0.145096$

\section{Gambar 3. Hasil Uji Normalitas}

Berdasarkan Gambar 3, diketahui bahwa nilai probabilitas Jarque- Berra sebesar 0.145096 dan lebih besar dari tingkat $a=5 \%$, yang berarti data terdistribusi normal.

2) Uji Multikolinearitas

Penilaian pada Uji Multikolinearitas dengan menggunakan metode VIF, yaitu sebesar 10.00. Apabila nilai pada setiap koefisien korelasi pada variabel bebas melebihi 10.00, artinya data terjangkit masalah multikolinearitas. Sebaliknya, apabila bernilai dibawah 10.00, artinya data terbebas dari multikolinearitas. Perhitungan VIF didasarkan pada buku Gujarati, Damodar N. pada tahun 2012, yang kemudian dilakukan dengan perhitungan manual dengan menggunakan Microsoft Excel (Suliyanto 2012).

Tabel 5. Hasil Uji Multikolinearitas

\begin{tabular}{|c|c|c|c|c|}
\hline & $\mathbf{r}$ & $\mathbf{r}^{\wedge} 2$ & TOL & VIF \\
\hline $\mathrm{X} 1 \mathrm{X} 2$ & 0.853156 & 0.727874 & 0.272126 & 3.674775 \\
\hline X1 X3 & 0.863167 & 0.745057 & 0.254943 & 3.922442 \\
\hline X2X3 & $\underline{0.822717}$ & $\underline{0.676863}$ & $\underline{0.323137}$ & $\underline{3.094665}$ \\
\hline
\end{tabular}

Berdasarkan Tabel 4.5, diketahui bahwa ketiga variabel memiliki nilai koefisien korelasi dibawah 10.00. Artinya, tidak terjadi multikolinearitas pada ketiga variabel bebas.

3) Uji Hetroskedastisitas

Salah satu cara melakukan pengujian heteroskedastisitas adalah dengan menggunakan Uji Glejser. Uji Glejser dilakukan dengan meregresikan nilai absolut residual terhadap variabel bebas. Kriteria penilaiannya adalah dengan melihat besarnya probabilitas masingmasing variabel. Apabila nilai probabilitas melebihi tingkat $a=5 \%$, maka tidak terjadi masalah heteroskedastisitas, begitu pula sebaliknya. 
Tabel 6. Hasil Uji Heteroskedastisitas

\begin{tabular}{lrrrl}
\hline \multicolumn{1}{c}{ Variable } & Coefficient & Std. Error & t-Statistic & Prob. \\
\hline APBD & -6.647692 & 26.75152 & -0.248498 & 0.8047 \\
TENAGA_KERJA & 117.6338 & 118.8445 & 0.989812 & 0.3269 \\
INVESTASI & -12.56012 & 10.56114 & -1.189277 & 0.2398 \\
C & -1271.576 & 1319.144 & -0.963941 & 0.3396 \\
\hline
\end{tabular}

Berdasarkan tabel diatas, nilai probabilitas dari ketiga variabel lebih besar dari tingkat $a=5 \%$, yang menandakan bahwa ketiga variabel terbebas dari heteroskedastisitas.

4) Uji Autokorelasi

Pengujian Autokorelasi dilakukan dengan melihat besarnya nilai Durbin Watson pada hasil estimasi Fixed Effect Model dan dibandingkan dengan nilai dL dan dU. Apabila nilai Durbin Watson berada diantara nilai dU dan 4-dU maka tidak terjadi autokorelasi dalam model. Namun, uji data panel menurut Gujarati and Porter (2012) tidak memerlukan uji asumsi klasik, seperti uji normalitas dan uji autokorelasi. Kemudian dari sudut pandang Basuki (2015), menyatakan bahwa uji autokorelasi pada data cross section atau panel pada dasarnya tidak berguna. Basuki mengatakan, autokorelasi hanya akan dilakukan pada data time series. Menurut Winarno (2017), autokorelasi lebih mudah ditampilkan pada data time series karena disebabkan oleh data runtut waktu dan dalam data time series, pengamatan disusun secara kronologis. Oleh karena itu, kemungkinan ada korelasi antara pengamatan berurutan.

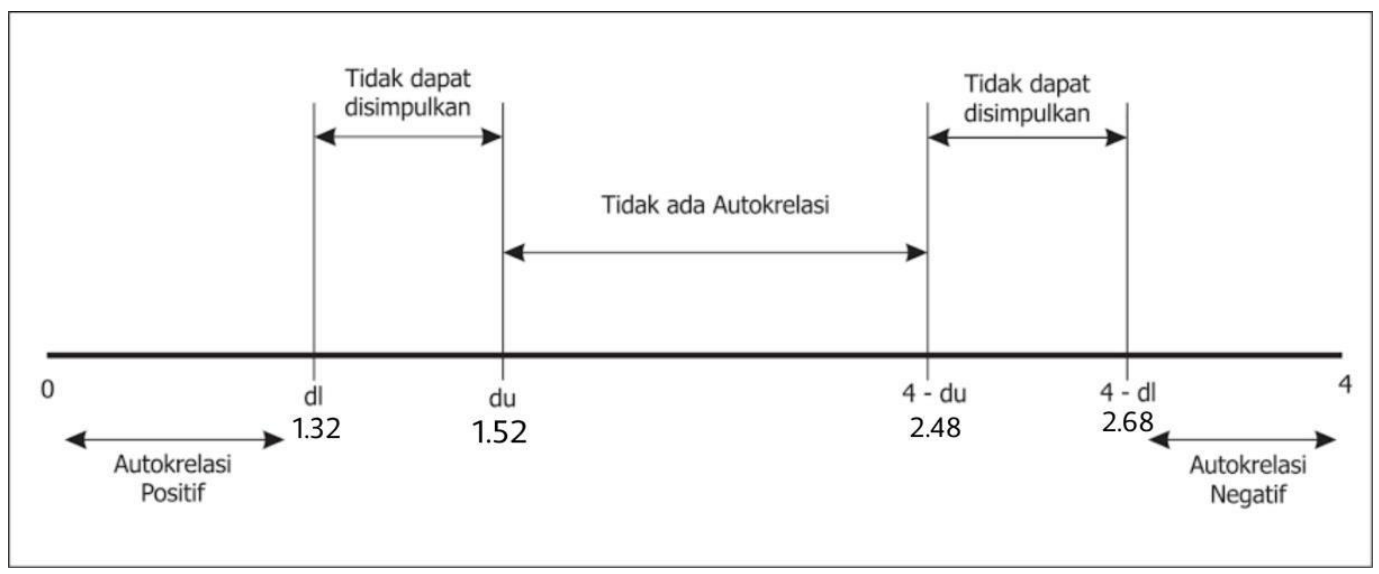

Gambar 4. Hasil Uji Autokorelasi

Berdasarkan Tabel 4.2, diketahui bahwa nilai Durbin Watson sebesar 0.61 dengan dL sebesar 1.32 dan dU sebesar 1.52. Dari gambar diatas diketahui bahwa nilai 0.61 terletak di area autokorelasi positif. 


\section{Pembahasan}

\section{Analisis Aglomerasi Berdasarkan Indeks Herfindahl-Hirschman}

\section{a. Koridor Jawa}

Koridor Jawa yang merupakan pusat pendorong industri dan jasa nasional termasuk dalam kategori aglomerasi tinggi dibandingkan koridor lain selama 10 tahun terakhir dan terus mangalami peningkatan disetiap tahunnya. DKI Jakarta berkontribusi besar pembentukan PDRB Koridor Jawa, yaitu sebesar 29.94\% dengan kontribusi terrendah oleh DI Yogyakarta yaitu sebesar 1.49\%. Tingginya nilai PDRB DKI Jakarta dikarenakan provinsi DKI Jakarta yang merupakan ibu kota Republik Indonesia, dimana provinsi ini menjadi pusat kegiatan ekonomi, politik, dan kebudayaan nasional. DKI Jakarta juga merupakan salah satu dari 20 daftar megalopolitan menurut catatan Bank Dunia. Selain itu, dalam daftar kawasan industri di Indonesia yang didapatkan melalui Kementerian Perindustrian Republik Indonesia, terdapat 2 kawasan industri besar di DKI Jakarta, yaitu Jakarta Industrial Estate Pulogadung yang sebesar 500,00 Ha dan Kawasan Berikat Nusantara yang sebesar 594,70 Ha. Tentunya kedua kawasan industri tersebut memiliki peran yang sangat besar terhadap perekonomian DKI Jakarta.

\section{b. Koridor Sumatera}

Koridor Sumatera yang merupakan sentra produksi dan pengolahan hasil bumi dan lumbung energi nasional menjadi koridor dengan tingkat aglomerasi ekonomi sedang. Koridor Sumatera mengalami penurunan aglomerasi ekonomi pada 6 tahun terakhir. Perekonomian koridor Sumatera didominasi oleh provinsi Sumatera Utara sebesar 23.39\%, dengan PDRB terrendah oleh provinsi Kepulauan Bangka Belitung yaitu hanya sebesar 2.21\% terhadap perekonomian koridor Sumatera. Hal tersebut dikarenakan Sumatera Utara merupakan salah satu daerah penghasil komoditi kelapa sawit terbesar di Indonesia. Tingginya permintaan akan produk olahan kelapa sawit ini menyebabkan luasnya area perkebunan kelapa sawit terus meningkat yang diikuti dengan peningkatan upaya produksi per satuan lahan oleh Dinas Perkebunan Provinsi Sumatera Utara melalui program intensifikasi dan program penanaman kembali terhadap tanaman tua yang memerlukan peremajaan. Perkebunan karet juga menjadi sumber penerimaan daerah melalui ekspor. Upaya peningkatan produktivitas usaha tani karet terus ditingkatkan terutama dalam pengembangan teknologi budidaya karet. Selain itu, di Sumatera Utara juga terdapat PT. Agincourt Resource Martabe Gold Mine yang merupakan perusahaan tambang yang bergerak di bidang eksplorasi, penambangan, dan pengolahan mineral batangan emas dan perak dengan lahan seluas 130.252 hektar. Adanya perkebunan kelapa sawit dan karet, serta industri tambang di Sumatera Utara akan berkontribusi besar terhadap pembentukan PDRB Sumatera Utara.

\section{c. Koridor Bali - Nusa Tenggara}

Koridor dengan tingkat aglomerasi ekonomi rendah, yang pertama adalah koridor Bali - Nusa Tenggara yang merupakan pintu gerbang pariwisata nasional dan pendukung panga nasional. Perekonomian koridor Bali-Nusa Tenggara didominasi oleh provinsi Bali dengan kontribusi sebesar 51.32\%, sedangkan Nusa 
Tenggara Timur dan Nusa Tenggara Barat masing-masing berkontribusi sebesar $26.96 \%$ dan $21.72 \%$. Permasalahan yang dihadapi oleh koridor ini diantaranya populasi penduduk yang tidak merata, tingkat investasi yang masih sangat rendah dibandingkan dengan koridor lain, serta ketersediaan infrastruktur penunjang perekonomian yang masih terbatas. Maka, diperlukan percepatan dan perluasan pembangunan ekonomi yang difokuskan pada 3 sektor utama, yaitu pariwisata, perikanan, dan peternakan. Sektor pariwisata merupakan kegiatan ekonomi utama yang akan terus dikembangkan karena masih banyak potensi parisiwata yang belum dikembangkan secara optimal di koridor ini. Pariwisata pada koridor BaliNusa Tenggara memiliki prospek yang sangat baik dengan Bali sebagai pusat pengembangan pariwisata karena adanya bandara internasional Ngurah Rai dan Nusa Tenggara sebagai pendukung potensi dan sumberdaya alam, serta budaya yang dimilikinya.

\section{d. Koridor Kalimantan}

Diurutan keempat adalah Koridor Kalimantan yang merupakan pusat produksi dan pengolahan hasil tambang dan lumbung energi nasional. Korodor Kalimantan mengalami aglomerasi ekonomi yang rendah dan terus mengalami penurunan pada 10 tahun terakhir. Perekonomian di koridor Kalimantan didominasi oleh Kalimantan Timur dengan kontribusi sebesar 54,61\%. Tingginya PDRB provinsi Kalimantan Timur diantaranya karena adanya tambang batu bara terbesar di Indonesia yang bernama PT. Kaltim Prima Coal (KPC), yang membentang seluas 84.938 hektar. Perusahaan ini memiliki 4.500 karyawan dan lebih dari 20.000 karyawan bagian kontraktor. KPC mengalami penignkatan produksi di setiap tahunnya, dimana pada 2018 KPC memproduksi sebanyak 58 juta ton batu bara dan 2019 memproduksi sebesar 62 juta ton batu bara. Selainitu juga terdapat perkebunan sawit yang berkontibusi sebagai sumber pendapatan nasional berupa ekspor, menyerap tenaga kerja, menurunkan kemiskinan, serta meningkatkan kualitas lingkungan hidup. Namun rendahnya aglomerasi di koridor ini disebabkan karena adanya industri tambang yang terdapat pada 3 provinsi lain di koridor Kalimantan yang juga berperan sebagai penopang perekonomian koridor Kalimantan. Dimana Kalimantan Selatan memiliki PT Borneo Indobara dengan luas konsesi tambang sebesar 24.100 hektar, PT Adaro Indonesia dengan luas konsesi tambang sebesar 34.940 hektar, dan PT Arutmin Indonesia yang bergerak dibidang produksi batu bara untuk pembangkit listrik dan pabrik industri. Provinsi Kalimantan Barat memiliki PT Indonesia Chemical Alumina yang merupakan industri tambang pengolahan bijih bauksit menjadi alumina dengan kapasitas produksi sebesar 300.000 ton per tahun. Kalimantan Tengah memiliki PT Indo Muro Kencana yang merupakan tambang emas dengan luas 47.940 hektar.

\section{e. Koridor Sulawesi}

Koridor Sulawesi sebagai pusat produksi dan pengolahan hasil pertanian, perkebunan, perikanan, migas, dan pertambangan nasional masuk kedalam kategori aglomerasi rendah dengan Sulawesi Selatan yang mendominasi perekonomian sebesar 49,58\%. Permasalahan yang terdapat di koridor ini diantaranya rendahnya nilai PDRB per kapita, investasi yang masih rendah, dan 
infrastruktur yang belum memadai. Dimana Sumatera memiliki prospek yang bagus untuk pengembangan perkebunan kelapa sawit yang juga memiliki kendala dalam kondisi infrastruktur. Kunci utama pembangunan ekonomi adalan dengan adanya pembangunan infrastruktur guna memperluas konektivitas, sehingga akan menarik peluang investasi yang nantinya akan meningkatkan PDRB per kapita. Setiap provinsi di Sulawesi memiliki potensi sumber daya unggulannya masingmasing yang dibagi menjadi 6 pusat perekonomian, yaitu Makassar, Kendari, Mamuju, Palu, Gorontalo, dan Manado. Makassar yang merupakan ibu kota Sulawesi Selatan berperan sebagai pusat perdagangan, pusat kegiatan industri, pusat kegiatan pemerintakan, dan pusat jasa angkutan penumpang dan barang. Kendari yang merupakan ibu kota Sulawesi Tenggara, memiliki keunggulan di sektor perkebunan, pertanian, dan jasa, dengan tersedianya Bandar Udara Haluoleo dan Pelabuhan Kendari.

Mamuju sebagai ibu kota Sulawesi Barat yang memiliki potensi di sektor pertanian, perhutanan, dan perikanan. Palu yang merupakan ibu kota Sulawesi Tengah yang memiliki potensi pada industri pengangkutan dan pergudangan, perumahan, jasa perusahaan, penyedia makan dan minum, informasi dan komunikasi, dan penyedia akomodasi. Gorontalo yang memiliki potensi di sektor perikanan, pertambangan, perhutanan, dan pertanian. Manado sebagai ibu kota Sulawesi Utara, yang memiliki potensi pada sektor perdagangan, perhotelan dan restoran, pengangkutan dan komunikasi, dan jasa.

\section{f. Papua - Kepulauan Maluku}

Koridor Papua - Kepulauan Maluku sebagai pusat pengembangan pangan, perikanan, energi, dan pertambangan nasional yang difokuskan pada 5 kegiatan ekonomi utama, yaitu pertanian dan pangan, Merauke Integrated Food and Energy (MIFEE), tembaga, nikel, perikanan, dan migas. Koridor ini termasuk dalam kategori aglomerasi rendah. Namun dalam pembangunan ekonominya, koridor ini mengalami beberapa kendala, diantaranya PDRB yang rendah, investasi yang sangat rendah yang disebabkan oleh tingginya resiko usaha dan rendahnya kepastian usaha, infrastruktur yang belum memadai, serta jumlah populasi penduduk yang masih rendah. Perekonomian koridor Papua - Kepulauan Maluku didominasi oleh Provinsi Papua, dengan kontribusi terhadap PDRB sebesar 52,69\%, dimana besarnya PDRB Papua didukung oleh sektor pertambangan. PT Freeport Indonesia (PTFI) mengolah bijih yang mengandung tembaga, emas, dan perak. PTFI menjadi penghasil tambang emas terbesar di Indonesia yang menghasilkan 240kilogram emas murni sektiap harinya. PTFI juga menjadi perusahaan tambang yang berkontibusi terhadap Penerimaan Negara Bukan Pajak (PNBP) terbesar pada tahun 2018.

Kawasan Merauke ditetapkan sebagai lumbung pangan dan energi di Kawasan Timur Indonesia (KTI) dengan membentuk Merauke Integrated Food and Energy (MIFEE). Dimana MIFFEE merupakan kegiatan ekonomi yang difokuskan untuk usaha budidaya tanaman skala luas dengan konsep pertanian sebagai sistem industrial. Maluku sebagai lumbung ikan nasional karena potensi perikanannya yang melimpah. Maluku Utara sebagai pengolahan dan distribusi hasil perikanan, serta pertambangan nikel. Papua Barat memiliki komoditas 
unggulan yang meliputi kakao, pala, kopi, rumput laut, kelapa, dan ekowisata. Sedangkan Papua memiliki potensi pertambangan tembaga, emas, dan minyak gas.

\section{Pengaruh APBD Terhadap Aglomerasi Ekonomi}

Anggaran Pendapatan dan Belanja Negara (APBD) memiliki pengaruh positif yang signifikan terhadap aglomerasi ekonomi. Artinya, apabila APBD mengalami peningkatan, maka anglomerasi ekonomi di Indonesia pada khususnya di setiap koridor ekonomi di Indonesia juga mengalami peningkatan yang signifikan. APBD yang berpengaruh positif terhadap aglomerasi ekonomi tersebut disebabkan karena tujuan adanya APBD adalah untuk meningkatkan perekonomian daerah serta mendorong kegiatan-kegiatan ekonomi masyarakat, sehingga semakin tingginya Anggaran Pendapatan dan Belanja Daerah maka semakin terpusatnya kegiatan ekonomi di wilayah tersebut. Menurut Wagner, besarnya belanja pemerintah yang semakin meningkat, maka akan memicu perkembangan aktivitas ekonomi masyarakat. Hal ini sejalan dengan penelitian oleh Sutiono and Syafitri (2018) yang menganalisis tentang pengaruh belanja pemerintah terhadap ketimpangan pendapatan di Jawa Timur. Hasil penelitiannya menunjukkan bahwa belanja modal APBD memiliki pengaruh positif signifikan terhadap ketimpangan di Jawa Timur.

Penelitian lain oleh Getachew and Turnovsky (2015) yang dalam penelitiannya mendapatkan hasil bahwa belanja pemerintah untuk modal publik pada akhirnya akan menyebabkan ketimpangan pendapatan. Hasil penelitian ini juga sejalan dengan penelitian terdahulu oleh Hur (2014) yang menyatakan bahwa belanja modal oleh pemerintah mempengaruhi ketimpangan, dan memiliki hubungan yang positif. Penelitian selanjutnya dilakukan oleh Sabir (2015) yang menganalisa terkait faktor- faktor yang mempengaruhi ketimpangan dengan studi kasus di Provinsi Sulawesi Selatan. Hasil dari penelitian tersebut adalah bahwa alokasi belanja modal pada APBD berpengaruh signifikan dan berhubungan positif terhadap ketimpangan pendapatan di Sulawesi Selatan.

\section{Pengaruh Tenaga Kerja Terhadap Aglomerasi Ekonomi}

Tenaga kerja memiliki pegaruh negatif dan signifikan terhadap aglomerasi ekonomi pada koridor-koridor ekonomi di Indonesia. Hal tersebut memiliki arti bahwa apabila jumlah tenaga kerja di pada suatu koridor mengalami penurunan, maka aglomerasi ekonomi di koridor tersebut akan meningkat. Sebaliknya, apabila tenaga kerja mengalami peningkatan, maka aglomerasi ekonomi akan mengalami penurunan. Hubungan yang negatif ini disebabkan karena tenaga kerja di Indonesia sebagian besar bekerja pada sektor informal dibandingkan dengan sektor formal, yaitu sebesar 74.093.224 jiwa pekerja informal dan 55.272.968 jiwa pekerja formal pada tahun 2019 (Badan Pusat Statistik 2020b). Dengan besarnya pekerja sektor informal tersebut, nantinya akan menciptakan pemerataan ekonomi dengan taraf ekonomi menengah kebawah.

Hal ini sejalan dengan hasil peneltian oleh Word Bank (2016), bahwa sebagian besar tenaga kerja di Indonesia bekerja di sektor informal dengan penghasilan yang rendah. Pada akhirnya kondisi tersebut akan menciptakan 
pemerataan ekonomi pada kelas ekonomi menengah kebawah. Penelitian selanjutnya oleh Nadhifah and Wibowo (2021) yang memiliki hasil bahwa jumlah tenaga kerja memiliki pengaruh negatif dan signifikan terhadap ketimpangan. Kemudian, terdapat pula penelitian selanjutnya oleh Kurniawan and Sugiyanto (2013) terkait pengaruh jumlah orang yang bekerja terhadap ketimangan wilayah di Jawa Tengah pada tahun 2002-2010. Dimana hasil dari penelitian tersebut adalah jumlah orang yang bekerja memiliki pengaruh yang tidak signifikan serta memiliki hubungan yang negative terhadap ketimpangan wilayah.

Namun juga terdapat beberapa penelitian dengan hasil yang berbeda. Penelitian pertama oleh Distovianti (2019) yang menganalisis faktor-faktor yang mempengaruhi ketimpangan ekonomi. Hasilnya bahwa tenaga kerja memiliki pengaruh signifikan dan berhubungan positif terhadap ketimpangan ekonomi. Penelitian selanjutnya oleh Didia (2018) yang menganalisis ketimpangan pembangunan di Kawasan Kedungsepur. Hasilnya adalah variabel tenaga kerja yang direpresentasikan dengan TPAK memiliki pengaruh yang tidak signifikan namun berhubungan positif terhadap ketimpangan pembangunan.

\section{Pengaruh Investasi Terhadap Aglomerasi Ekonomi}

Investasi yang terdiri dari Penanaman Modal Asing (PMA) dan Penanaman Modal Dalam Negeri (PMDN) memiliki pengaruh positif yang tidak signifikan terhadap aglomerasi ekonomi pada koridor-koridor ekonomi di Indonesia. Artinya, apabila jumlah investasi pada suatu koridor mengalami peningkatan, maka akan meningkatkan tingkat aglomerasi. Sebaliknya, apabila investasi mengalami penurunan, maka akan meningkatkan aglomerasi ekonomi. Hirschman dalam Adisasmita (2005) menyatakan bahwa pertumbuhan ekonomi pada pusat pertumbuhan akan berpengaruh pada daerah sekitarnya dengan polarization effect dan trickling down effect. Ia mempercayai bahwa dengan berjalannya waktu, trickling down effect akan dapat mengatasi efek polarisasi dengan campur tangan pemerintah. Hal tersebut berarti trickling down effect akan terjadi pada wilayah sekitarnya yang selanjutnya akan memperkecil tingkat aglomerasi ekonomi di wilayah tersebut.

Hal ini sejalan dengan beberapa penelitian, yaitu yang pertama oleh Kusumo (2017) yang menganalisis ketimpangan pendapatan di Sulawesi Selatan. Hasil dari penelitian tersebut adalah bahwa PMA secara langsung berpengaruh tidak signifikan secara negatif terhadap ketimpangan pendapatan. Penelitian kedua oleh Rosmeli (2015) yang menganalisis dampak investasi dan tenaga kerja terhadap ketimpangan pembangunan di Kawasan Timur Indonesia. Hasilnya adalah, PMDN tidak memiliki pengaruh yang signifikan dan memiliki hubungan negatif terhadap ketimpangan pembangunan di Kawasan Timur Indonesia.

Penelitian selanjutnya oleh Putra (2019) yang menganalisis pengaruh pengeluaran pemerintah dan investasi terhadap ketimpangan pendapatan di Pulau Sulawesi. Hasilnya adalah investasi tidak bepengaruh terhadap ketimpangan pendapatan di Pulau Sulawesi, baik secara langsung maupun tidak. Penelitian selannjutnya oleh Prastiwi et al. (2020) yang menganalisis faktor-faktor yang mempengaruhi ketimpangan pendapatan di Pulau Jawa tahun 2014-2018. Hasil dari penelitian tersebut adalah investasi tidak memiliki pengaruh terhadap 
ketimpangan pendapatan di Pulau Jawa tahun 2014- 2018.

\section{SIMPULAN, KETERBATASAN, DAN SARAN}

\section{Kesimpulan}

a. Aglomerasi di tiap koridor ekonomi di Indonesia memiliki hasil yang bervariasi, dimana koridor Sumatera memiliki hasil aglomerasi ekonomi yang sedang mulai tahun 2010 hingga 2019. Koridor Jawa memiliki hasil aglomerasi ekonomi yang tinggi pada tahun 2010 hingga 2019. Koridor Bali - Nusa Tenggara, Kalimantan, Sulawesi, Papua-Kepulauan Maluku memiliki hasil aglomerasi ekonomi rendah mulai tahun 2010 hingga 2019. Hal ini sesuai dengan teori oleh Myrdal and Sitohang (1957) yang menyatakan bahwa adanya dampak balik (backwash effect) terjadi pada saat pertumbuhan ekonomi yang terjadi dalam suatu wilayah tertentu mengakibatkan berpindahnya sumber daya (misalnya tenaga kerja, modal, dan sebagainya) dari wilayah disekitar wilayah tersebut. Hal ini akan mengakibatkan wilayah yang pengalami pertumbuhan ekonomi tadi akan semakin maju dari wilayah disekitarnya dan wilayah sekitar akan semakin tertinggal, sehingga aglomerasi ekonomi akan terfokus di daerah maju saja.

b. APBD berpengaruh positif dan signifikan terhadap aglomerasi ekonomi pada koridor ekonomi di Indonesia. Hal tersebut dikarenakan alokasi APBD yang ditujukan untuk pembangunan ekonomi daerah yang belum merata di setiap daerah di suatu koridor. Tenaga kerja berpengaruh negative dan signifikan terhadap aglomerasi ekonomi pada koridor ekonomi di Indonesia. Hal tersebut dikarenakan tenaga kerja di Indonesia sebagian besar bekerja di sektor informal, sehingga menciptakan pemerataan perekonomian yang berada di kelas menengah kebawah. Investasi memiliki pengaruh positif namun tidak signifikan terhadap aglomerasi ekonomi pada koridor ekonomi di Indonesia. Hasil yang tidak signifikan ini disebabkan oleh data realisasi investasi yang terdiri dari penanaman modal asing dan penanaman modal dalam negeri mengalami fluktuasi pada tahun 2010-2019 sehingga menyebabkan investasi tidak berpengaruh terhadap aglomerasi ekonomi.

\section{Saran}

a. Guna mengatasi masalah aglomerasi ekonomi yang terpusat hanya di daerah maju saja, hendaknya dilakukan pembangunan pusat-pusat perekonomian yang menyeluruh, terutama pada daerah-daerah skala kecil dan menengah dengan memanfaatkan sumber daya yang ada. Dengan begitu, daerah-daerah skala kecil menengah juga akan mengalami perkembangan dan pertumbuhan ekonomi.

b. Anggaran pendapatan dan belanja negara perlu ditingkatkan efektivitasnya dalam memperluas pembangunan ekonomi hingga ke pelosok daerah. Sehingga, dampak dari alokasi APBD dapat dirasakan di seluruh daerah.

c. Penduduk yang bekerja di suatu daerah perlu mendapatkan dukungan untuk meningkatkan kualitasnya, terutama pada pekerja sektor informal. 
Dukungan yang dapat diberikan berupa kebijakan terkait peningkatan pendidikan, serta pelatihan-pelatihan yang dapat meningkatkan kemampuan dan pengetahuan tenaga kerja, sehingga dapat meningkatkan produktivitas kerja dan meningkatkan taraf perekonomian tenaga kerja sektor informal dengan perekonomian menengah kebawah.

d. Dalam upaya mengatasi aglomerasi ekonomi yang hanya terpusat di suatu wilayah, pemerintah hendaknya membuat kebijakan terkait investasi yang lebih memihak masyarakat setempat. Kebijakan tersebut terkait tenaga kerja lokal yang lebih banyak diperkerjakan dibandingkan dengan tenaga kerja asing. Serta pemerintah juga menyediakan infrastrukturinfrastruktur penunjang perekonomian, sehingga akan menarik modal asing dan modal dalam negeri untuk berinvestasi.

\section{DAFTAR PUSTAKA}

Adisasmita, R. 2005. Dasar-dasar ekonomi wilayah. Yogyakarta: Graha Ilmu.

Badan Pusat Statistik. 2020a. Jumlah Industri Pengolahan Besar dan Sedang, Jawa dan Luar Jawa Tahun 2014-2018. In . Jakarta: BPS Indonesia.

Badan Pusat Statistik. 2020b. PDB Menurut Lapangan Usaha Seri 2010 Tahun 20152019. In . Jakarta: BPS Indonesia.

Basuki, A. 2015. Pengantar Ekonometrika (Dilengkapi Penggunaan Eviews). Yogyakarta: Danisa Media.

Didia, K. A. 2018. Analysis of Development Inequality in Kedungsepur Area. Economics Development Analysis Journal 7 (2): 210-216.

Distovianti, R. C. 2019. Analisis Faktor-Faktor yang Mempengaruhi Ketimpangan Pendapatan di Indonesia. Universitas Katolik Parahyangan.

Getachew, Y. Y., and S. J. Turnovsky. 2015. Productive government spending and its consequences for the growth--inequality tradeoff. Research in Economics 69 (4): 621-640.

Gujarati, D. N. 2003. Basic Econometrics. Forth Edition. Singapura: McGraw-Hill.

Gujarati, D. N., and D. C. Porter. 2012. Dasar-Dasar Ekonometrika, Edisi 5. Jakarta: Salemba Empat.

Hur, S. 2014. Govt. spending and inclusive growth in developing Asia.

Hyman, D. N. 2014. Public finance: A contemporary application of theory to policy. Cengage Learning.

Krugman, P. 1998. Space: the final frontier. Journal of Economic perspectives 12 (2): $161-174$.

Kuncoro, M. 2002. Ekonomika Aglomerasi: Dinamika dan Dimensi Spasial Kluster Industri Indonesia. Yogyakarta: UPP STIM YKPN.

- 2006. Ekonomi Pembangunan. Jakarta: Salemba Empat.

- 2010. Masalah, kebijakan, dan politik ekonomika pembangunan.

Kurniawan, B. R. A., and F. X. Sugiyanto. 2013. Pengaruh pertumbuhan ekonomi, share sektor industri dan pertanian serta tingkat jumlah orang yang bekerja terhadap ketimpangan wilayah antar kabupaten/kota di Jawa Tengah tahun 2002-2010. Diponegoro Journal of Economics 2 (1): 69-82.

Kusumo, F. B. 2017. Analisis Ketimpangan Pendapatan di Sulawesi Selatan. Universitas Hasanuddin Makassar. 
Myrdal, G., and P. Sitohang. 1957. Economic theory and under-developed regions.

Nadhifah, T., and M. G. Wibowo. 2021. DETERMINAN KETIMPANGAN PENDAPATAN MASYARAKAT DI DAERAH ISTIMEWA YOGYAKARTA. Jurnal Ekonomi Dan Bisnis 24 (1): 39-52.

Pramesti, D. A. D. G., and I. N. M. Yasa. 2019. Pengaruh Investasi dan Inflasi terhadap Pertumbuhan Ekonomi dan Ketimpangan Distribusi Pendapatan di Kabupaten Klungkung. E-Jurnal EP Unud 8(11): 2562-2590.

Prastiwi, D. H., L. T. Laut, and R. Destiningsih. 2020. ANALISIS FAKTORFAKTOR YANG MEMPENGARUHI KETIMPANGAN PENDAPATAN DI PULAU JAWA TAHUN 2014-2018. DINAMIC: Directory Journal of Economic 2 (1): 33-50.

PUTRA, F. P. 2019. PENGARUH PENGELUARAN PEMERINTAH DAN INVESTASI TERHADAP KETIMPANGAN PENDAPATAN DI PULAU SULAWESI. Universitas Hasanuddin.

Rosmeli, R. 2015. Dampak Investasi dan Tenaga Kerja terhadap Ketimpangan Pembangunan Kawasan Timur Indonesia. Jurnal Paradigma Ekonomika 10 (2).

Sabir. 2015. Pengaruh Alokasi Belanja Modal Terhadap Pertumbuhan Ekonomi, Ketimpangan Pendapatan, Penyerapan Tenaga Kerja, dan Kesejahteraan Masyarakat Kabupaten/Kota Di Provinsi Sulawesi Selatan Tahun 2008-2013. Universitas Malang.

Snyder, C. M., W. Nicholson, and R. Stewart. 2012. Microeconomic theory: Basic principles and extensions.

Sodik, J., D. Nuryadin, and D. Iskandar. 2007. Aglomerasi dan Pertumbuhan Ekonomi: Peran Karakteristik Regional. Parallel Session IVA, Urban and Regional, Fakultas Ekonomi UPN Veteran.

Suharsimi, A. 2006. Prosedur penelitian suatu pendekatan praktik. Jakarta: Rineka Cipta: $120-123$.

Suliyanto. 2012. Ekonometrika Terapan. Yogyakarta: Andi.

Susanti, E. D. 2018. Environmental Kuznet Curve: Hubungan Pertumbuhan Ekonomi dengan Degradasi Kualitas Udara Dalam Pencapaian MilleniumDevelopment Goals (MDGs) di Indonesia. Universitas Negeri Yogyakarta.

Sutiono, F., and W. Syafitri. 2018. Belanja Kementerian/Lembaga, Belanja APBD, Kontribusi Sektoral, dan Ketimpangan Pendapatan di Jawa Timur. Indonesian Treasury Review: Jurnal Perbendaharaan, Keuangan Negara dan Kebijakan Publik 3 (3): 186-201.

Tambunan, T. T. H. 2001. Perekonomian Indonesia (Teori dan Temuan Empiris).

Todaro, M. P. 2000. Pembangunan Ekonomi di Dunia Ketiga Edisi Ketujuh. Jakarta: erlangga.

Winarno, W. W. 2017. Analisis ekonometrika dan statistika dengan eviews.

Word Bank. 2016. Ketimpangan yang Semakin Lebar. Jakarta: World Bank. 